\title{
STUDI PELACAKAN KETERSERAPAN LULUSAN \\ JURUSAN TEKNIK ELEKTRO \\ FAKULTAS TEKNIK DAN KEJURUAN \\ UNIVERSITAS PENDIDIKAN GANESHA
}

\author{
Oleh \\ I Nyoman Pasek Nugraha \\ Jurusan Teknik Elektronika, FTK, Undiksha
}

\begin{abstract}
Abstrak
Jurusan Teknik Elektro, Fakultas Teknik dan Kejuruan (FTK) Undiksha harus berbenah diri guna memenuhi tuntutan kemajuan ilmu pengetahuan, teknologi, dan kebutuhan pasar. Salah satu bentuk mekanisme yang dapat dilakukan adalah studi pelacakan yang hingga saat ini belum pernah terlaksana bagi lulusan jurusan Teknik Elektro.

Metode pengumpulan data yang digunakan adalah kuesioner. Responden penelitian ini adalah alumni Jurusan Teknik Elektro yang terpilih sebagai anggota sampel penelitian, di samping terdiri dari sejumlah tokoh kunci yang diasumsikan mewakili kalangan pemakai lulusan (selected samples).

Dari 53 orang lulusan yang berhasil diamati ternyata tingkat keterserapan lulusan Jurusan Teknik Elektro sangat tinggi terutama dibidang swasta (26 orang atau 49,06\%), 7 orang $(13,2 \%$ ) yang diketahui melakukan wiraswasta, 6 orang $(11,3 \%)$ sebagai pegawai negeri sipil (PNS) dan 9 orang $(16,98 \%)$ berstatus honorer, serta 5 orang $(9,43 \%)$ sisanya sedang studi lanjut.
\end{abstract}

Kata kunci : studi pelacakan, lulusan

\begin{abstract}
Electrical Engineering Department, Faculty of Technical and Vocational (FTK) Undiksha must improve itself in order to meet the demands of the progress of science, technology and market needs. One form of mechanism that can be done is a tracer study to date has never done for graduates majoring in Electrical Engineering.

Data collection methods used were questionnaires. The research respondents were graduates of Electrical Engineering Department who was elected as a member of the research sample, in addition to consisting of a number of key figures who are assumed to represent the users of graduates (selected samples).

Of the 53 people turned out graduates who successfully observed absorption rate of graduates of Electrical Engineering Department is very high, especially the private sector (26 persons or $49.06 \%$ ), 7 persons
\end{abstract}


(13.2\%) are known to self-employed, 6 persons (11.3\%) as civil servants (PNS) and 9 people $(16.98 \%)$ honorary status, and 5 persons $(9.43 \%)$, the remainder being furtherstudy.

Keywords: tracer study, graduates

\section{Pendahuluan}

Jurusan Teknik Elektro FTK UNDIKSHA sudah meluluskan 60 orang, yang telah tersebar di berbagai pelosok daerah Bali. Namun demikian, hingga kini belum pernah dilakukan studi pelacakan terhadap pemakaian lulusan oleh berbagai pihak, terutama yang bertalian dengan bidang kerja dan kualitasnya sebagai outcome dan yang lebih luas yaitu prestasi di tempat kerjanya. Para lulusan itu tercatat sebagai anggota ikatan alumni, baik ikatan alumni Undiksha maupun ikatan alumni jurusan. Salah satu tugas alumni untuk memberikan umpan balik (feedback) secara teratur dan berkesinambungan kepada almamaternya. Oleh sebab itu ikatan alumni terutama ikatan alumni jurusan belum bisa memberikan masukan kepada institusi maupun jurusan untuk berbagai keperluan seperti : pengembangan kurikulum, hubungan kemasyarakatan (humas), bursa kekaryaan dan kerjasama dengan berbagai instansi terkait/stakeholders.

Sebagai lembaga pendidikan yang bernaung dibawah Fakultas Teknik dan Kejuruan (FTK) Undiksha, Jurusan Teknik Elektro harus berbenah diri untuk bisa mengikuti perkembangan tersebut dan sebagai tindak lanjutnya perlu diadakan pembaharuan dan penyempurnaan dalam semua bidang guna memenuhi tuntutan kemajuan ilmu pengetahuan, teknologi, dan kebutuhan pasar. Hal ini harus dilakukan supaya lulusan yang dihasilkan oleh lembaga Undiksha dan Jurusan Teknik Elektro khususnya mempunyai kualitas sesuai kebutuhan pasar/masyarakat. Dari perspektif institusi produsen, Jurusan Teknik Elektro Undiksha mempunyai kewajiban untuk merespon tuntutan perubahan itu melalui pembenahan proses pembelajaran yang diciptakan di kampus, sedangkan 
dari perspektif lulusan mempunyai kewajiban bagi produsen untuk memberikan pelayanan purna kelulusan melalui mekanisme tertentu. Salah satu bentuk mekanisme itu adalah studi pelacakan yang hingga saat ini belum pernah terlaksana bagi lulusan jurusan Teknik Elektro.

Perubahan kebijakan pada tingkat makro nasional yang sangat mendasar untuk direspon oleh pihak produsen tenaga kependidikan dan para lulusan di lapangan adalah implementasi kurikulum berbasis kompetensi pada berbagai jenjang pendidikan (Dede Rosyada, 2004 : 45). Bagi LPTK, Kep. Mendiknas No. 232/U/2000 dan No. 045/U/2002 memberikan konsekuensi pada perubahan kurikulum ditingkat pendidikan tinggi tenaga kependidikan, sementara lulusan hasil PBM berdasarkan kurikulum lama (Content Base Curriculum Development) perlu menyesuaikan diri dengan perkembangan yang baru.

Para alumni dan ikatan alumni yang ada belum berfungsi optimal terutama dalam kewajibannya sebagai jembatan penghubung antara LPTK dengan lulusan (alumni) guna memperoleh manfaat secara timbal balik. Motivasi institusi produsen tenaga kependidikan untuk mendayagunakan umpan balik dari para alumni untuk perbaikan dan pengembangan institusi masih jauh dari memadai. Hubungan kemasyarakatan (Humas) belum dirasakan sebagai suatu kebutuhan, padahal dalam era globalisasi dan otonomi daerah yang semakin menguat kehumasan itu sudah menjadi keperluan yang amat signifikan. Termasuk di dalamnya adalah kerjasama yang efektif dengan stakeholders.

Alumni, baik secara individual maupun secara organisatoris belum didayagunakan secara optimal, padahal dalam manajemen perguruan tinggi yang efektif dan efisien pendayagunaan ikatan alumni dan para alumni sudah terbukti mampu memberikan kontribusi secara memadai bagi pengembangan kampus/almamaternya. Pada sisi lainnya para alumni belum memperoleh semacam pelayanan purna lulus melalui berbagai mekanisme, seperti seminar, workshop, ataupun home comming day. 
Belum ditemukenali dengan cermat dan akurat tingkat relevansi kompetensi lulusan Jurusan Teknik Elektro FTK UNDIKSHA dengan tuntutan kerja yang menjadi tugasnya sebagai penghasil tenaga kerja siap pakai sehingga dapat digunakan sebagai umpan balik guna pengembangan kurikulum baru dari Jurusan Teknik Elektro yang berbasis kompetensi. Selain itu dapat digunakan sebagai bahan pertimbangan untuk menyelenggarakan program pengabdian pada masyarakat dalam rangka hubungan masyarakat, kerjasama dengan dunia usaha pemakai alumni, dan pelayanan purna lulus bagi para alumni. Jadi permasalahan yang dikaji dalam penelitian ini dapat dirumuskan sebagai berikut. 1 . Bagaimanakah profil keterserapan lulusan Jurusan Teknik Elektro di pasar kerja? 2. Bagaimanakah kompetensi kebutuhan pasar kerja pada lulusan Jurusan Teknik Elektro?

Pengembangan FTK sebagai bagian dari pendidikan kejuruan harus berorientasi pada demand-driven yaitu berorientasi ke pasar kerja (Sutarto,H ; 1998). Sistim deman-driven ini juga mengacu pada kompetensi. Jadi perencanaan, pelaksanaan, dan evaluasi program pendidikan kejuruan, dalam hal ini Teknik Elektro harus merupakan hasil kajian bersama antara pihak perguruan tinggi sebagai pensuplai dan dunia kerja sebagai pemakai.

Di samping pendekatan kompetensi di atas, dilihat dari segi waktu adalah wajib bagi kalangan akademisi/kampus untuk mengevaluasi kurikulum yang digunakan minimal dalam kurun waktu lima tahun, sejalan dengan kemajuan sains dan teknologi yang diduga terjadi secara signifikan, untuk menunjukkan tingkat relevansi dari kurikulum.

Dalam pengembangan kurikulum suatu jurusan dipandang layak jika tidak hanya melibatkan para ekspert/akademisi, namun juga kalangan yang disebut stakeholders termasuk para pemakai lulusan suatu jurusan/program studi. Selain itu acuan pengembangan kurikulum secara nasional harus pula digunakan sebagai dasar dalam rangka mencapai standar mutu nasional. Dalam hal ini juga harus digunakan untuk 
mengembangkan kurikulum lokal yang secara akademik disebut kurikulum institusional. Hal ini mengacu pada Kep. Mendiknas No. 232/U/2000 dan No. 045/U/2002.

Adanya pergeseran sistim manajemen dari model Terpusat (centralized) ke model Mandiri (decentralization) yaitu pendidikan kejuruan secara otonomi dapat menentukan kebijakan lokal dalam penyelenggaraan kurikulum. Jurusan Teknik Elektro Undiksha sampai saat ini telah 3 (tiga) kali melakukan penyempurnaan kurikulum, sampai akhirnya disepakati untuk memberlakukan kurikulum konsentrasi mulai semester genap tahun ajaran 2007/2008 yang terdiri dari konsentrasi Sistem Tenaga, Komputer Jaringan, dan Pendingin ( Buku Pedoman Studi Undiksha tahun 2008).

Pengembangan kurikulum jurusan Teknik Elektro dengan pendekatan yang baru (kompetensi) tidak bisa dilepaskan dari modal awal yang dimiliki sebagaimana diterapkan pada mahasiswa lama yang telah tamat belajar yang kini berstatus alumni dan telah berkarya di bidang kelistrikan. Mengukur kesenjangan kompetensi yang terjadi, dapat dilakukan melalui identifikasi pada pernyataan alumni tentang berbagai kekurangan bekal kompetensi yang diperolehnya semasa pendidikan dengan tuntutan kerja yang dihadapi di lapangan, di samping melalui penggalian berdasarkan penilaian pihak pemakai terhadap berbagai kelemahan ataupun kekurangan di bidang kemampuan dari para alumni yang dipekerjakannya (penilaian atasan pemakai).

Penelitian ini ditujukan untuk menggali dan menemukenali berbagai kesenjangan kemampuan/kompetensi alumni Jurusan Teknik Elektro FTK UNDIKSHA Singaraja dibandingkan dengan tuntutan normatif kemampuan yang diperlukan sesuai dengan keperluan pelaksanaan tugas-tugasnya sebagai tenaga kependidikan di lapangan yang harus sejalan pula dengan perubahan kebijakan pendidikan yang terjadi di samping sejalan pula dengan kemajuan jaman. 
Di dalam pelaksanaannya melibatkan tim peneliti dari Jurusan. Tim ini sebagai pengumpul data yang bertugas menghubungi responden terpilih di beberapa Kabupaten/Kota di daerah Propinsi Bali. Jangka waktu penelitian ini adalah enam bulan efektif. Metode utama pengumpulan data yang digunakan adalah kuesioner dalam bentuk kuesioner tipe tertutup dan terbuka. Responden penelitian ini adalah alumni Jurusan Teknik Elektro yang terpilih sebagai anggota sampel penelitian, di samping terdiri dari sejumlah tokoh kunci yang diasumsikan mewakili kalangan pemakai lulusan (selected samples). Pengumpulan data dari tokoh kunci kalangan pemakai juga akan dilengkapi dengan wawancara terstruktur jika kuesioner terbukti belum mampu menggali data secara lengkap.

\section{PEMBAHASAN}

Pada studi pelacakan yang telah dilakukan berhasil mendata sebanyak 53 (lima puluh tiga) orang alumni Jurusan Teknik Elektro yang tersebar pada berbagai bidang pekerjaan namun ada juga beberapa diantaranya yang melanjutkan studi ke S1 Teknik Elektro. Adapun hasil studi pelacakan tersebut seperti terlihat pada tabel berikut:

Tabel 1. Pekerjaan Alumni

\begin{tabular}{|c|c|c|c|c|c|c|c|c|}
\hline \multirow{2}{*}{ No } & \multirow{2}{*}{$\begin{array}{l}\text { Tahun } \\
\text { masuk }\end{array}$} & \multicolumn{2}{|c|}{$\begin{array}{c}\text { Jenis } \\
\text { kelamin }\end{array}$} & \multicolumn{5}{|c|}{ Bidang pekerjaan (orang) } \\
\hline & & $\mathbf{L}$ & $\mathbf{P}$ & PNS & $\begin{array}{c}\text { Honore } \\
\mathbf{r}\end{array}$ & Swasta & Wiraswasta & Studi \\
\hline 1 & 2002 & 15 & 2 & 2 & 4 & 6 & 3 & 2 \\
\hline 2 & 2003 & 20 & 2 & 2 & 4 & 14 & 1 & 1 \\
\hline 3 & 2004 & 9 & 1 & 2 & 1 & 4 & 2 & 1 \\
\hline 4 & 2005 & 4 & - & - & - & 2 & 1 & 1 \\
\hline & mlah & 48 & 5 & $\begin{array}{c}6 \\
(11,3 \\
\%)\end{array}$ & $\begin{array}{c}9 \\
(16,98 \\
\%)\end{array}$ & $\begin{array}{c}26 \\
(49,06 \\
\%)\end{array}$ & $\begin{array}{c}7 \\
(13,2 \%)\end{array}$ & $\begin{array}{c}5 \\
(4,93\end{array}$ \\
\hline
\end{tabular}

JPTK, UNDIKSHA, Vol. 6, No. 1, Januari 2009 : 63 - 72 
Dari tabel diatas terlihat bahwa sebagian besar alumni bekerja pada bidang swasta (26 orang atau 49,06\%) yang tersebar diberbagai perusahaan seperti : PLN ( 7 orang ), kontraktor listrik (6 orang), PLTGU (3 orang), Bank (2 orang), bidang kesehatan (2orang), Finance (2 orang), teknisi di supermarket (1 orang), teknisi di Bali TV (1 orang), bidang komputer jaringan (1 orang), dan teknisi di bandara Ngurah Rai ( 1 orang). Sementara itu ada 7 orang $(13,2 \%)$ yang diketahui melakukan wiraswasta setelah lulus dari Jurusan Teknik Elektro baik bidang listrik , elektronika maupun bidang lainnya. Sehingga kalau dilihat dari persentase yang berwiraswasta dapat dilihat kalau minat alumni untuk berwiraswasta masih sangat rendah. Sedangkan 6 orang $(11,3 \%)$ yang sudah sebagai pegawai negeri sipil (PNS) semuanya bersetatus sebagai teknisi dan 9 orang $(16,98 \%)$ yang bersetatus honorer umumnya sedang menunggu sebagai PNS. Serta 5 orang $(9,43 \%)$ sisanya sedang studi lanjut di UNUD dan ITB.

Dari wawancara dengan alumni ternyata banyak yang tidak langsung mendapatkan pekerjaan sesuai dengan apa yang diharapkan, seperti apa yang dialami Ni Made Wahyuni (alumni angkatan tahun 2002) setelah tamat dari Jurusan Teknik Elektro harus bekerja sebagai teknisi di CV. Surya Motor dengan gaji RP 700.000,- dan baru tahun 2007 berhasil diterima sebagai teknisi (PNS) di Jurusan Teknik Elektro. Sementara I Gede Putra Suryawan (alumni angkatan 2003) memiliki pengalaman yang tidak jauh berbeda dimana setelah lulus tahun 2006 diterima sebagai teknisi di Astra Motor dengan gaji Rp. 300.000,- dan pada tahun 2007 diterima sebagai pegawai tetap PT. PLN (Persro). Namun banyak juga yang langsung dapat diterima sebagai pegawai sesuai harapannya, seperti Ni Komang Wik Suartini (alumni angkatan 2002) begitu lulus langsung diterima di Bank NSIP. Jaabir (alumni angkatan 2003) setelah tamat tahun 2006 langsung dapat diterima sebagai pegawai tetap di Bank BNI'46. Namun ada juga sudah diterima sebagai tenaga honorer sebelum lulus dan setelah lulus langsung diterima sebagai PNS 
seperti yang dialami oleh I Made Dony Suwindia Astina Putra (alumni angkatan 2004).

Dari 53 orang responden yang berhasil di data ternyata $50 \%$ mengawali karir sebagai pegawai/teknisi magang yang dijalani sekitar 12 tahun sampai akhirnya mendapat pekerjaan tetap sebagai teknisi dengan gaji yang layak. Diantara mereka juga ada yang melajutkan studi sesuai dengan keperluan di tempat magang, seperti yang di alami Kadek Suar Wibawa yang diangkat sebagai tenaga honorer di SMKN 3 Singaraja dan untuk kepentingan sekolah akhirnya Kadek Suar Wibawa dikirim studi lanjut ke ITB dengan biaya dari SMKN 3 Singaraja. Hal semacam ini juga di alami oleh Sang Made Ari Jayadiputra yang diangkat sebagai tenaga honorer di SMAN 1 Singaraja, karena untuk kepentingan sekolah akhirnya yang bersangkutan dikirim untuk studi lanjut ke Undiksha.

Namun 50\% sisanya bisa langsung diterima sebagai teknisi dengan gaji awal sekitar 700 ribu rupiah, dan diantara mereka ada yang sudah naik jabatannya menjadi pengawas dengan gaji antara Rp.1.200.000,- sampai 1.500.000,- bahkan ada yang sudah menjabat sebagai asisten manager di salah satu perusahaan kontraktor listrik di Denpasar. Sementara itu alumni yang tidak senang dibawah perintah atasan cenderung memilih untuk wirswasta mandiri, seperti yang dilakukan oleh I Putu Arya Widhi Antara yang memilih berwiraswasta di bidang elektronika yang mendirikan sebuah perusahaan jasa servis elektronika dengan spesialisasi dinamo. Sementara Gede Suryawan Palguna memilih untuk wiraswasta bidang jasa instalasi listrik, jaringan dan pemancar TV. Secara umum alumni Jurusan Teknik Elektro tidaklah kesulitan dalam mendapatkan pekerjaan pertama setelah lulus dari Hurusan Teknik Elektro.

Dari 53 orang responden (alumnus) hampir semuanya menyatakan kesiapannya dalam memasuki dunia kerja. Artinya pendidikan yang diperoleh di Jurusan Teknik Elektro dapat memberikan kemaslatan kepada mereka dalam memasuki dunia kerja. Bahkan para 
alumnus tersebut hampir semuanya menyatakan cukup mudah untuk mendapatkan pekerjaan setelah lulus dari Jurusan Teknik Elektro. Dengan sistem kurikulum yang "mix" dalam artian belum terkonsentrasi ternyata para alumni tidak mengalami kesulitan dalam memasuki dunia kerja. Hal ini terbukti dari pekerjaan yang di geluti alumni pada berbagai bidang seperti bidang listrik, elektronika, telekomunikasi, komputer (perangkat keras), bahkan ada pula yang meggeluti bidang pendingin (AC dan kulkas). Hal ini menunjukkan bahwa apa yang dipelajari selama kuliah sudah cukup memberikan bekal kepada alumni dalam rangka memasuki dunia kerja. Dan ternyata semua dari mereka menyatakan mampu bersaing di tempat kerja, hal ini menunjukkan bahwa model pembelajaran di Jurusan Teknik Elektro sudah mampu memberikan bekal yang cukup memadai kepada alumni.

\section{Simpulan}

Dari hasil pengamatan dan pembahasan diperoleh bahwa

1. Dari 53 orang lulusan yang berhasil diamati ternyata tingkat keterserapan lulusan Jurusan Teknik Elektro sangat tinggi terutama dibidang swasta (26 orang atau 49,06\%) yang tersebar diberbagai perusahaan, 7 orang $(13,2 \%)$ yang diketahui melakukan wiraswasta setelah lulus dari Jurusan Teknik Elektro baik bidang listrik, elektronika maupun bidang lainnya, 6 orang $(11,3 \%)$ yang sudah sebagai pegawai negeri sipil (PNS) semuanya bersetatus sebagai teknisi dan 9 orang $(16,98 \%)$ yang bersetatus honorer umumnya sedang menunggu sebagai PNS, serta 5 orang $(9,43 \%)$ sisanya sedang studi lanjut.

2. Dari informasi yang diperoleh dari stakeholders diketahui bahwa lulusan Jurusan Teknik Elektro mampu menyaingi lulusan perguruan tinggi lain baik negeri maupun swasta. 


\section{DAFTAR PUSTAKA}

Boediono. 1997. Pendidikan dan Perubahan Sosial Ekonomi. Yogyakarta : Aditya Media.

Rosyada, Dede. 2004. Paradigma Pendidikan Demokratis. Jakarta : Prenada Media.

Sukamto.2001. Perubahan Karakteristik Dunia kerja dan Revitalisasi Pembelajaran dalam Kurikulum Pendidikan Kejuruan. Pidato Pengukuhan Guru Besar. Yogyakarta : Universitas Negeri Yogyakarta.

Sutarto,H. 1998. Sebuah Reformasi Untuk Pendidikan Kejuruan Menjelang 2020. Jurnal PTK. Yogyakarta : IKIP.

Kep. Mendiknas Nomor 232/U/2000 tentang Pedoman Penyusunan Kurikulum Pendidikan Tinggi dan Penilaian Hasil Belajar.

Kep. Mendiknas Nomor 045/U/2002 tentang Kurikulum Inti Pendidikan Tinggi 